\title{
Neuroprotective Effects of MK-801 in vivo: Selectivity and Evidence for Delayed Degeneration Mediated by NMDA Receptor Activation
}

\author{
A. C. Foster, R. Gill, and G. N. Woodruff \\ Merck Sharp and Dohme Research Laboratories, Neuroscience Research Centre, Terlings Park, Harlow, Essex, CM20 \\ 2QR, United Kingdom
}

The ability of the noncompetitive $\boldsymbol{N}$-methyl-D-aspartate (NMDA) receptor antagonist MK-801 to prevent neuronal degeneration in the rat striatum and hippocampus caused by intracerebral injection of excitotoxins has been examined. Excitotoxic damage was assessed after $7 \mathrm{~d}$, using histological and biochemical [choline acetyltransferase (ChAT) glutamate decarboxylase (GAD)] measurements. Systemically administered MK-801 was found to protect against neurodegeneration caused by NMDA (200 nmol) and the naturally occurring NMDA receptor agonist quinolinate (120$600 \mathrm{nmol}$ ) but not against that induced by kainate ( $5 \mathrm{nmol}$ ) or $\alpha$-amino-3-hydroxy-5-methylisoxazole-4-propionate (AMPA; $50 \mathrm{nmol}$ ), indicating a selectivity for NMDA receptormediated neuronal loss. Neurotoxicity caused by NMDA (200 $\mathrm{nmol})$ or quinolinate (200 $\mathrm{nmol}$ ) was prevented by MK-801 (1-10 $\mathrm{mg} / \mathrm{kg}$, i.p.) administered in a single dose after excitotoxin injection. In the striatum, significant protection of cholinergic neurons (assessed by ChAT measurements) was observed when MK-801 was given up to $5 \mathrm{hr}$ after injection of NMDA or quinolinate, whereas protection of GABAergic neurons (assessed by GAD measurements) was obtained up to 2 hr. The results suggest that GABAergic neurons degenerate more rapidly than cholinergic neurons. The competitive NMDA receptor antagonist 3-[( \pm )-2-carboxypiperazin-4-yl]-propyl-1-phosphonate (100 mg/kg, i.p.) gave partial protection of striatal neurons when administered $1 \mathrm{hr}$ after quinolinate injection. In the rat hippocampus, administration of $10 \mathrm{mg} / \mathrm{kg}$ MK-801 i.p. $1 \mathrm{hr}$ after quinolinate injection caused almost complete protection of pyramidal and granule neurons, whereas the degeneration of CA3/CA4 pyramidal neurons caused by kainate injection was unaffected. These observations indicate that neurons in rat striatum and hippocampus do not die as an immediate consequence of exposure to high concentrations of NMDA agonists but that a delayed process is involved that requires NMDA receptor activation. In this respect, intracerebral injections of NMDA agonists may mimic the pathological changes that are thought to occur in the brain following periods of cerebral ischemia, where delayed neuronal degeneration occurs.

\footnotetext{
Received Feb. 17, 1988; revised Apr. 25, 1988; accepted Apr. 29, 1988.

We are most grateful for the secretarial assistance of Eleanor Brawn and Christine Jones and the photographic expertise of Roy Hammans.

Correspondence should be addressed to Dr. Alan C. Foster, Merck Sharp and Dohme Ltd., Neuroscience Research Centre, Terlings Park, Eastwick Road, Harlow, Essex, CM20 2QR, UK.

Copyright (C) 1988 Society for Neuroscience $0270-6474 / 88 / 124745-10 \$ 02.00 / 0$
}

Neurons of the mammalian CNS degenerate when exposed to abnormally high concentrations of excitatory amino acids such as L-glutamate and L-aspartate (Lucas and Newhouse, 1957; Olney et al., 1971). An overstimulation of receptors that normally mediate the excitatory effects of these neurotransmitters (and are located on the dendrites of vulnerable neurons) is proposed as the mechanism by which neurons die (Olney et al., 1971), and the term "excitotoxicity" has been coined to describe this phenomenon (Olney, 1974). Excitatory amino acid receptors have been divided into 3 subtypes named after the prototypical agonists, $N$-methyl-D-aspartate (NMDA), quisqualate, and kainate (Watkins and Evans, 1981; Foster and Fagg, 1984). Studies with selective agonists indicate that excitotoxic effects occur following activation of each receptor subtype (Schwarcz et al., 1978; Morgan, 1987).

Injection of excitotoxins directly into the CNS has been used to cause discrete "axon-sparing" lesions of brain regions and to provide animal models of human neurodegenerative disorders (Coyle and Schwarcz, 1976; McGeer and McGeer, 1976; Fuxe et al., 1983). Thus, excitotoxic lesions in the rat striatum reproduce many of the morphological and biochemical changes that occur in the basal ganglia of Huntington's disease victims (Fuxe et al., 1983). However, it is questionable whether acute injections of excitotoxins can provide animal models of degenerative states such as Huntington's disease that evolve over a period of years. In many respects direct excitotoxin injections reproduce more closely the pathological changes that occur during cerebral ischemia, when massive acute elevations of extracellular levels of excitatory amino acids are observed in the CNS (Benveniste et al., 1984; Hagberg et al., 1985). The neuronal degeneration that results occurs particularly in brain regions possessing a high density of NMDA receptors (see Wieloch, 1985) and can be reduced by administration of selective NMDA receptor antagonists (Rothman, 1984; Simon et al., 1984; Gill et al., 1987a, b). These observations suggest that an excitotoxic mechanism involving NMDA receptors may be a cause of ischemia-induced neuronal degeneration. An interesting feature of the neuronal degeneration resulting from periods of global forebrain ischemia is that susceptible neurons may not die immediately but degenerate at times as long as $24-48 \mathrm{hr}$ after the initial insult (Kirino, 1982; Pulsinelli et al., 1982; Gill et al., 1987a). Recent evidence indicates that such delayed neuronal degeneration may also occur in patients who are resuscitated following cardiopulmonary arrest (Petito et al., 1987).

Experiments in this laboratory have shown that the novel anticonvulsant (+)-5-methyl-10,11-dihydro-5H-dibenzo[a,d]cyclohepten-5,10-imine maleate (MK-801) is a potent, se- 
lective, and noncompetitive NMDA receptor antagonist (Wong et al., 1986). Upon systemic administration, MK-801 prevents the loss of striatal and hippocampal neurons in the rat caused by direct injection of NMDA (Foster et al., 1987a) and protects against the degeneration of hippocampal neurons in the gerbil and rat caused by a brief period of forebrain ischemia (Gill et al., $1987 \mathrm{a}, \mathrm{b})$. In the present series of experiments we have examined the specificity of MK-801 for NMDA receptor-mediated neurodegenerative events by assessing its ability to prevent neuronal degeneration in the rat brain caused by direct injection of the endogenous NMDA receptor agonist quinolinate (Stone and Perkins, 1981; Schwarcz et al., 1983), the selective quisqualate receptor agonist DL- $\alpha$-amino-3-hydroxy-5-methylisoxazole-4-propionate (AMPA; Krogsgaard-Larsen et al., 1980) and the kainate receptor agonist, kainate. In addition, we have used MK-801 to evaluate the possibility that, like the situation in cerebral ischemia, the neuronal degeneration that occurs following direct excitotoxin injection occurs by a delayed process. Somc of these rcsults have appeared previously in abstract form (Foster et al., 1987b, c).

\section{Materials and Methods}

\section{Stereotaxic injections and drug treatment}

For the majority of experiments, male Sprague-Dawley rats (250-350 $\mathrm{gm})$ were anesthetized with Equithesin $(82 \mathrm{ml})$ Nembutal, $42.5 \mathrm{gm}$ chloral hydrate, $21.26 \mathrm{gm} \mathrm{MgSO}, 396 \mathrm{ml}$ propane-1,2-diol, $100 \mathrm{ml}$ ethanol in 1 liter of distilled water; $3.75 \mathrm{ml} / \mathrm{kg}$ i.p.) and placed in a Kopf stereotaxic frame. An incision was made in the scalp and the surface of the skull exposed. Excitotoxin injections were made into the right striatum or hippocampus by means of a 28 -gauge stainless steel needle linked to a Hamilton syringe. Injections were made via a $1-2 \mathrm{~mm}$ diameter hole made in the skull using a small hand drill. For the striatum, coordinates of injection were A $0.5 \mathrm{~mm}$ from bregma, L $2.6 \mathrm{~mm}$ from midline, and V $4.4 \mathrm{~mm}$ from dura. For the hippocampus, coordinates of injection were A $-3.0 \mathrm{~mm}$ from bregma, $\mathrm{L} 2.0 \mathrm{~mm}$ from midline, and $V 3.0 \mathrm{~mm}$ from dura. Quinolinate, NMDA, kainate, and AMPA were dissolved in $1 \mathrm{M} \mathrm{NaOH}$, the pH adjusted to 7.4 with $1 \mathrm{M} \mathrm{HCl}$ and brought to the required volume with a solution of $10 \mathrm{~mm}$ sodium phosphate buffer ( $\mathrm{pH} 7.4$ ) in $0.9 \%$ saline. Excitotoxins were injected in a volume of $1 \mu \mathrm{l}$ delivered over a period of $2 \mathrm{~min}$, and the injection needle was left in place for a further 1.5 min to allow diffusion of the injected solution. After the scalp was apposed with wound clips, animals were allowed to recover for $7 \mathrm{~d}$. In one group of animals, anesthesia was induced and maintained by a mixture of $2 \%$ isoflurane $/ 70 \% \mathrm{~N}_{2} \mathrm{O} / 30 \%$ $\mathrm{O}_{2}$ during intrastriatal injection of quinolinate.

MK-801 or 3-[( 1)-2-carboxypipcrazin-4-yl]-propyl-1-phosphonate (CPP) was dissolved in $0.9 \%$ saline and administered as a single injection i.p. $(1 \mathrm{ml} / \mathrm{kg}$ body weight $)$ at the designated times before or after excitotoxin injection.

\section{Enzyme measurements}

Seven days after excitotoxin injection, rats were killed and their brains removed; both striata were dissected and frozen on dry ice. After measuring the wet weight, individual striata were sonicated for $10 \mathrm{sec}$ in 20 $\mathrm{vol}(\mathrm{wt} / \mathrm{vol})$ of $50 \mathrm{~mm}$ Tris- $\mathrm{HCl}(\mathrm{pH} 7.4), 0.2 \%$ Triton X-100. Aliquots of these homogenates were then taken for determination of choline acetyltransferase (ChAT) and glutamate decarboxylase (GAD) activities.

ChAT assay. A modification of the method of Bull and OderfeldNovak (1971) was used to measure ChAT activity. A $10 \mu$ sample of striatal homogenate was incubated in duplicate for $20 \mathrm{~min}$ at $37^{\circ} \mathrm{C}$ in a solution containing $300 \mathrm{mM} \mathrm{NaCl}, 6 \mathrm{~mm}$ choline chloride, $75 \mu \mathrm{M}$ physostigmine, $50 \mathrm{~mm}$ sodium phosphate buffer (pH 7.0), $0.5 \mathrm{mg} / \mathrm{ml}$ $\mathrm{BSA}$, and $50 \mu \mathrm{M}\left[1-{ }^{14} \mathrm{C}\right]$ acetyl coenzyme $\mathrm{A}$ (diluted to a specific activity of $1 \mathrm{mCi} / \mathrm{mmol}$ ) in a final volume of $100 \mu \mathrm{l}$. Blank values were obtained by replacing the homogenate with $10 \mu \mathrm{l}$ of $50 \mathrm{~mm}$ Tris- $\mathrm{HCl}(\mathrm{pH} \mathrm{7.4)}$, $0.2 \%$ Triton $\mathrm{X}-100$. The incubation was terminated by the addition of $0.4 \mathrm{ml}$ ice-cold distilled water and the tubes placed on ice. The ${ }^{14} \mathrm{C}$-ACh produced was separated from unreacted ${ }^{14} \mathrm{C}$-acetyl coenzyme $\mathrm{A}$ by ionexchange chromatography. Small (approximately $2 \mathrm{~cm}$ ) columns of
Dowex $1 \times 8$ chloride resin were prepared in pasteur pippettes and washed with $1 \mathrm{ml}$ of distilled water. A sample $(0.4 \mathrm{ml})$ of the reaction mixture was applied onto a column followed by a $1 \mathrm{ml}$ wash with distilled water, and the total eluate $(1.4 \mathrm{ml})$ was collected in a $20 \mathrm{ml}$ plastic scintillation vial. This procedure was optimal for eluting ${ }^{14} \mathrm{C}$ ACh with retention of ${ }^{14} \mathrm{C}$-acetyl coenzyme $\mathrm{A}$ on the column. After addition of $10 \mathrm{ml}$ scintillation fluid and thorough mixing, radioactivity in the samples was determined by scintillation counting in a beta counter.

GAD assay. A modification of the ${ }^{14} \mathrm{CO}_{2}$-trapping method of Wilson et al. (1972) was used to determine GAD activity. Fifty milliliters of striatal homogenate was incubated in duplicate for $30 \mathrm{~min}$ at $37^{\circ} \mathrm{C}$ in a solution containing $25 \mathrm{~mm}$ potassium phosphate buffer ( $\mathrm{pH} 6.8$ ), 1 mM EDTA, $1 \mathrm{~mm}$ 2-mercaptoethanol, 0.2\% Triton X-100, $0.5 \mathrm{~mm}$ pyridoxal phosphate, and $5 \mathrm{mM} \mathrm{L}-\left[1-^{14} \mathrm{C}\right]$-glutamate (diluted to a specific activity of $0.2 \mathrm{mCi} / \mathrm{mmol}$ ) in a final volume of $100 \mu \mathrm{l}$. Blank values were obtained by substituting $50 \mu \mathrm{l}$ of $50 \mathrm{~mm}$ Tris-HCl buffer ( $\mathrm{pH} 7.4$ ), $0.2 \%$ Triton $\mathrm{X}-100$ for the striatal homogenate. The assay was performed in $5 \mathrm{ml}$ polypropylene tubes and ${ }^{14} \mathrm{CO}_{2}$ produced was trapped in Whatman GF/B filters soaked with $200 \mu$ l of $1 \mathrm{M}$ hyamine hydroxide in methanol contained within plastic scintillation minivials linked to the assay tubes by a sleeve of rubber tubing. The reaction was stopped by injection of $200 \mu \mathrm{l}$ of $10 \mathrm{~mm}$ acetic acid in methanol through the rubber sleeve via a syringe, and the tubes were left at room temperature overnight to ensure complete trapping of ${ }^{14} \mathrm{CO}_{2}$ produced. After addition of $4 \mathrm{ml}$ scintillation fluid to the minivials, radioactivity was determined by scintillation counting in a beta counter.

The results of the enzyme assays are expressed as the percentage reduction of activity in the injected versus contralateral striatum, calculated using the equation $[(D-I) / D] \times 100$, where $D$ is dpm produced in homogenate from the contralateral side and $I$ is dpm produced in homogenate from the injected side, after subtraction of blank values.

\section{Histology}

Seven days after excitotoxin injection, rats were perfused transcardially with $0.9 \%$ saline followed by a solution of $10 \%$ formaldehyde containing $5 \%(\mathrm{wt} / \mathrm{vol})$ sucrose under deep Equithesin anesthesia. The brains were removed and placed in 5\% formaldehyde containing 30\% (wt/vol) sucrose for at least $2 \mathrm{~d}$, after which $40 \mu \mathrm{m}$ sections were cut using a freezing sledge microtome and stained with cresyl violet.

\section{Materials}

NMDA and AMPA were obtained from Cambridge Research Biochemicals (Cambridge, UK), CPP was obtained from Tocris Ltd. (Essex, UK), and quinolinate and kainate from Sigma (St. Louis). $\left[1-{ }^{14} \mathrm{C}\right]$-acetyl coenzyme A $(54 \mathrm{mCi} / \mathrm{mmol})$ and $\mathrm{L}-\left[1-{ }^{14} \mathrm{C}\right]$-glutamate $(58 \mathrm{mCi} / \mathrm{mmol})$ were purchased from Amersham (UK).

\section{Results}

Both neurochemical and histological methods were used to evaluate neuronal degeneration in the rat striatum or hippocampus occurring $7 \mathrm{~d}$ after local injection of quinolinate, NMDA, kainate, or AMPA. A quantitative assessment of the loss of striatal cholinergic and GABAergic neurons was made by measuring the activities of the respective marker enzymes ChAT and GAD in striatal homogenates. The morphology of the injected striatum or hippocampus was assessed by light microscopy in cresyl violet-stained coronal brain sections.

\section{Effects of MK-801 on neurodegeneration caused by quinolinate and NMDA}

\section{MK-801 administered before excitotoxin injection}

Enzyme measurements. In control animals, intrastriatal injection of $120,200,300$, or $600 \mathrm{nmol}$ quinolinate resulted in a dose-related reduction of both ChAT and GAD activities in the injected striatum compared with the contralateral, uninjected side (Table 1). At the lowest dose of $120 \mathrm{nmol}$ quinolinate, the percentage reduction of GAD activity was greater than that for ChAT ( $p<0.01$, paired $t$ test), indicating a preferential vul- 

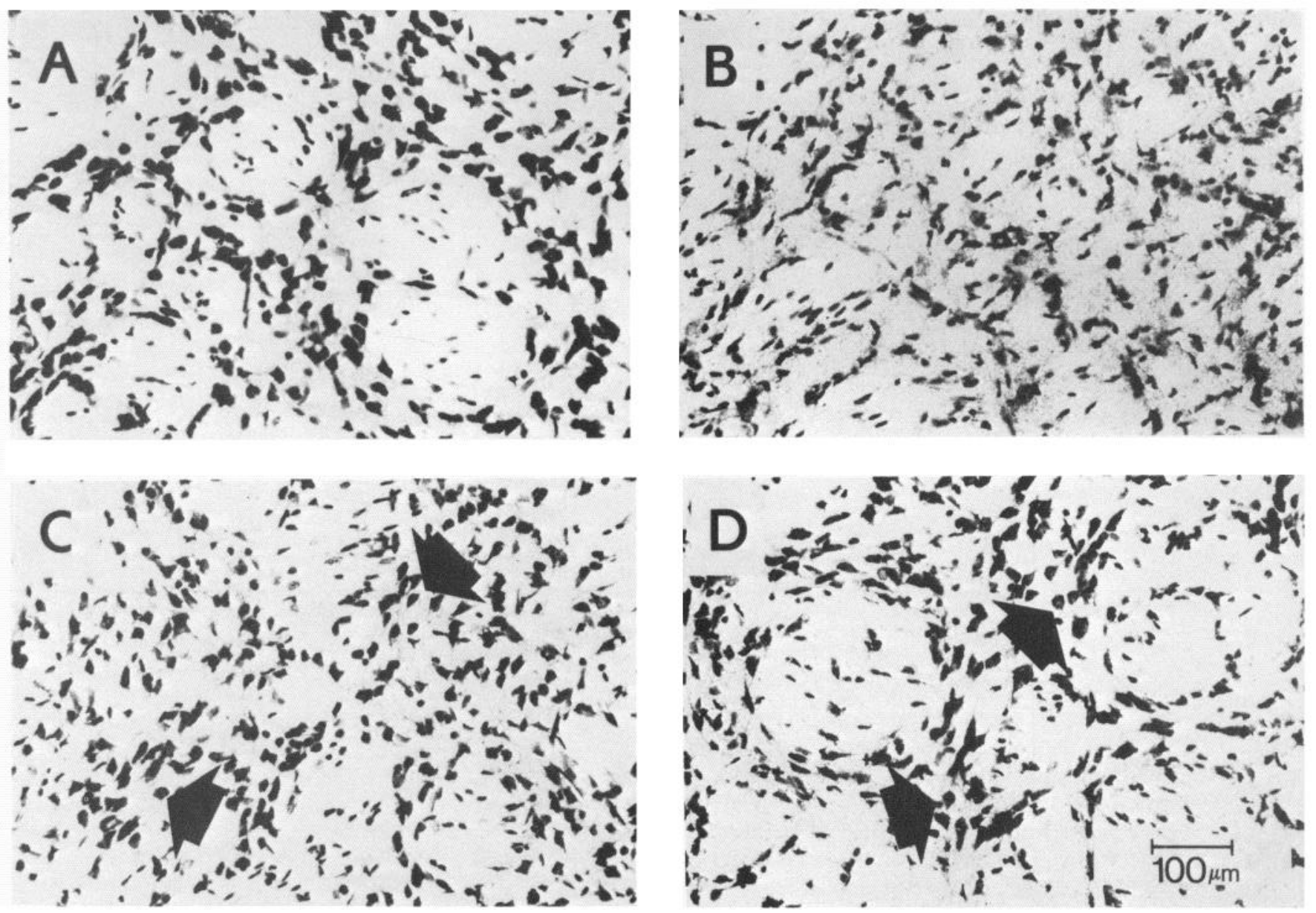

Figure 1. Protection by MK-801 of quinolinate-induced neurotoxicity in the rat striatum. Light micrographs of $40 \mu \mathrm{m}$ cresyl violet-stained coronal sections of rat brain $7 \mathrm{~d}$ after intrastriatal injections. $A$, Saline injection. $B$, Injection of $120 \mathrm{nmol}$ quinolinate. Note extensive loss of striatal neurons and proliferation of glial cells. $C$, Treatment with $10 \mathrm{mg} / \mathrm{kg}$ MK-801 (i.p.) $1 \mathrm{hr}$ prior to injection of 200 nmol quinolinate. Normal-appearing neurons are present in close proximity to the injection site (arrows). D, Treatment with $10 \mathrm{mg} / \mathrm{kg} \mathrm{MK}-8011 \mathrm{hr}$ after injection of $120 \mathrm{nmol}$ quinolinate. Normal-appearing neurons surround the injection site (arrows).

nerability of GABAergic versus cholinergic neurons. Pretreatment of rats with $10 \mathrm{mg} / \mathrm{kg}$ MK-801 (i.p.) $1 \mathrm{hr}$ prior to quinolinate injection almost completely prevented the reductions of ChAT and GAD activities at each dose of quinolinate (Table 1). To investigate the dose-response relationship of this protection by MK-801, lower doses of the drug were tested against 120 and $200 \mathrm{nmol}$ quinolinate. With $120 \mathrm{nmol}$ quinolinate, the decrease in ChAT activity was significantly prevented by $3 \mathrm{mg} /$ $\mathrm{kg}$ MK-801, but not $1 \mathrm{mg} / \mathrm{kg}$ MK-801, whereas both doses produced significant attenuation of the decrease in GAD activity (Table 1). In contrast, doses of 1 or $3 \mathrm{mg} / \mathrm{kg}$ MK-801 were unable to prevent the reductions of ChAT or GAD activities caused by $200 \mathrm{nmol}$ quinolinate (Table 1), despite the fact (as indicated above) that $10 \mathrm{mg} / \mathrm{kg} \mathrm{MK}-801$ gave virtually complete protection.

Histology. Injection of 200 or $300 \mathrm{nmol}$ quinolinate into the rat striatum resulted $7 \mathrm{~d}$ later in an extensive area of striatal neuron degeneration and gliosis extending for several millimeters around the site of injection ( $n=4$ in each group). Injection of $10 \mathrm{mg} / \mathrm{kg} \mathrm{MK}-801$ (i.p.) $1 \mathrm{hr}$ before intrastriatal quinolinate caused essentially complete protection of neuronal loss and prevented gliosis $(n=4$ in each group; Fig. $1 C)$. In the rat hippocampus, injection of $60 \mathrm{nmol}$ quinolinate resulted $7 \mathrm{~d}$ later in the degeneration of all hippocampal pyramidal and granule neurons and a marked gliosis within a few millimeters of the injection site $(n=5$; Fig. $2 B)$. MK- $801(10 \mathrm{mg} / \mathrm{kg}$, i.p.) administered $1 \mathrm{hr}$ prior to quinolinate injection prevented gliosis and caused complete protection of hippocampal neurons, except some CA1 pyramidal cells and dentate granule cells in the immediate proximity of the injection site ( $n=5$, Fig. $2 C$ ).

\section{MK-801 administered after excitotoxin injection}

Enzyme measurements. The excitotoxin-induced reduction of ChAT and GAD activities could be prevented by MK- 801 administered at various times after excitotoxin injection. As shown in Figure $3 A$, the reduction of striatal ChAT activity caused by $200 \mathrm{nmol}$ quinolinate was completely prevented by a single 10 $\mathrm{mg} / \mathrm{kg}$ dose of MK-801 administered i.p. either 1 or $2 \mathrm{hr}$ after quinolinate injection. Partial protection of the decrement in ChAT activity was observed when MK-801 was given $5 \mathrm{hr}$ after quinolinate, with no significant protection at 8 or $24 \mathrm{hr}$. Analysis of the same striatal homogenates for GAD activity indicated partial protection by $10 \mathrm{mg} / \mathrm{kg}$ MK- 801 at 1 and $2 \mathrm{hr}$ after quinolinate but no difference from control at 5,8 , or $24 \mathrm{hr}$ (Fig. $3 B)$.

Essentially the same pattern of protection by MK- 801 was 
Table 1. Prevention of quinolinate-induced reductions in rat striatal ChAT and GAD activities by 1 hr pretreatment with MK-801 (1, 3, or $10 \mathrm{mg} / \mathrm{kg}$, i.p.)

\begin{tabular}{|c|c|c|c|c|}
\hline \multirow{2}{*}{$\begin{array}{l}\text { (A) ChAT a } \\
\text { Dose of } \\
\text { quinolinate } \\
\text { (nmol) }\end{array}$} & \multirow[b]{2}{*}{ Control } & \multicolumn{3}{|c|}{ \% Decrease of ChAT activity } \\
\hline & & $1 \mathrm{mg} / \mathrm{kg}$ & $3 \mathrm{mg} / \mathrm{kg}$ & $10 \mathrm{mg} / \mathrm{kg}$ \\
\hline 120 & $44.3 \pm 7.9(15)$ & $41.6 \pm 7.9 \quad(10)$ & $25.2 \pm 7.8^{a}(10)$ & $3.8 \pm 1.5^{b}(10)$ \\
\hline 200 & $74.7 \pm 8.3(5)$ & $61.5 \pm 10.9(5)$ & $61.3 \pm 5.9(5)$ & $5.0 \pm 1.2^{b}(5)$ \\
\hline 300 & $87.3 \pm 7.3(5)$ & NT & $\mathrm{NT}$ & $4.9 \pm 2.8^{b}(5)$ \\
\hline 600 & $96.6 \pm 1.2(4)$ & NT & NT & $8.7 \pm 4.1^{b}(5)$ \\
\hline
\end{tabular}

(B) GAD activity

\begin{tabular}{llllr}
$\begin{array}{l}\text { Dose of } \\
\text { quinolinate } \\
\text { (nmol) }\end{array}$ & Control & \multicolumn{4}{l}{ \% Decrease of GAD activity } \\
\cline { 2 - 5 } & $1 \mathrm{mg} / \mathrm{kg}$ & $3 \mathrm{mg} / \mathrm{kg}$ & $10 \mathrm{mg} / \mathrm{kg}$ \\
\hline 120 & $61.2 \pm 5.2(15)$ & $47.2 \pm 7.9^{a}(10)$ & $33.8 \pm 8.4^{b}(10)$ & $4.6 \pm 2.4^{b}(10)$ \\
200 & $87.5 \pm 3.6(5)$ & $78.2 \pm 6.2(5)$ & $74.0 \pm 6.5(5)$ & $7.4 \pm 6.5^{b}(5)$ \\
300 & $86.4 \pm 5.8(5)$ & NT & NT & $7.3 \pm 4.3^{b}(5)$ \\
600 & $97.1 \pm 0.8(4)$ & NT & NT & $18.8 \pm 7.9^{b}(5)$
\end{tabular}

Enzyme measurements were made in homogenates of striatum from rats killed $7 \mathrm{~d}$ after quinolinate injection. Values are the percentage decrease of enzyme activity in the injected compared with the contralateral striatum and are the means + SEM of the number of animals given in parentheses. Values in the contralateral striatum were as follows: $\mathrm{ChAT}, 15.02 \pm 0.27 \mathrm{nmol} / \mathrm{hr} / \mathrm{mg}$ tissue; GAD, $19.02 \pm 1.26 \mathrm{nmol} / \mathrm{hr} / \mathrm{mg}$ tissue (means $\pm \mathrm{SEM}$ of 10 animals). NT, not tested.

${ }^{a} p<0.05 ;{ }^{b} p<0.01$ (significantly different from control values by Dunnett's test).

apparent when striatal neuron degeneration was induced by intrastriatal injection of $200 \mathrm{nmol}$ NMDA, a dose that resulted in an equivalent degree of reduction in ChAT and GAD activities as that which occurred following $200 \mathrm{nmol}$ quinolinate (Fig. 4). Thus, the loss of ChAT activity was attenuated by $10 \mathrm{mg} /$ kg MK-801 administered 1, 2, or $5 \mathrm{hr}$, but not $24 \mathrm{hr}$, after NMDA injection (Fig. 4A). The loss of GAD activity measured in the same samples was reduced by MK-801 at 1 or $2 \mathrm{hr}$, but not 5 or $24 \mathrm{hr}$, after NMDA injection (Fig. $4 B$ ).

The dose-response relationship of protection resulting from delayed administration of MK-801 was investigated at a time point of $1 \mathrm{hr}$ after intrastriatal injection of $200 \mathrm{nmol}$ quinolinate (Fig. 5). With 1,3 , and $10 \mathrm{mg} / \mathrm{kg}$ MK-801, a clear dose-dependent protection of the reductions in ChAT and GAD activities caused by quinolinate was apparent. Note that, in contrast to pretreatment of animals with the same doses of MK-801 (see Table 1), a significant effect of the 1 and $3 \mathrm{mg} / \mathrm{kg}$ doses was obtained by administration $1 \mathrm{hr}$ after injection of $200 \mathrm{nmol}$ quinolinate.

Histology. The protective effects of delayed MK-801 administration against quinolinate-induced neurodegeneration were confirmed histologically. Injection of $120 \mathrm{nmol}$ quinolinate into the striatum of control animals resulted $7 \mathrm{~d}$ later in a loss of intrinsic neurons and a marked gliosis for a few millimeters around the injection site $(n=5 ; \mathrm{Fig} .1 B)$. Administration of 10 $\mathrm{mg} / \mathrm{kg} \mathrm{MK-801} \mathrm{(i.p.)} 1 \mathrm{hr}$ after quinolinate injection resulted in virtually complete protection of striatal neurons in all animals $(n=5$; Fig. $1 D)$. Delayed administration of MK-801 also prevented quinolinate-induced neuronal degeneration in the rat hippocampus. Thus, in 5 animals receiving an intrahippocampal injection of $60 \mathrm{nmol}$ quinolinate followed $1 \mathrm{hr}$ later by 10 $\mathrm{mg} / \mathrm{kg}$ MK-801 (i.p.), 3 had no signs of neuronal loss except for a small number of CA1 and CA4 pyramidal cells in the immediate vicinity of the injection site (Fig. $2 D$ ), whereas the remaining 2 had a small area of $\mathrm{CA} 1$ pyramidal cell degeneration but complete protection of other hippocampal neurons. This was in marked contrast to the extensive degeneration of all hippocampal cells for several millimeters around the site of injection in control animals (Fig. $2 B$; see above).

\section{Effects of MK-801 on striatal neurodegeneration caused by kainate and AMPA}

The selectivity of MK-801 as an antagonist of NMDA receptormediated neuronal degeneration was assessed in the rat striatum by determining its effects on the reductions of ChAT and GAD activities resulting from intrastriatal injection of kainate or AMPA. As shown in Table 2, intrastriatal injection of $5 \mathrm{nmol}$ kainate resulted $7 \mathrm{~d}$ later in an approximately $60 \%$ reduction of ChAT and GAD activities in the injected striatum as compared with the contralateral, uninjected side. MK $-801(10 \mathrm{mg} /$ $\mathrm{kg}$, i.p.) given either $1 \mathrm{hr}$ before or 2 or $5 \mathrm{hr}$ after kainate injection was unable to prevent the reductions in ChAT and GAD activities caused by kainate. Intrastriatal injection of $50 \mathrm{nmol}$ AMPA resulted $7 \mathrm{~d}$ later in a significantly ( $p<0.01$; paired $t$ test) greater reduction of GAD activity than ChAT activity (Table 2), indicating a preferential vulnerability of striatal GABAergic neurons to this excitotoxin. Administration of MK-801 $(10 \mathrm{mg} / \mathrm{kg}$, i.p.) at $1 \mathrm{hr}$ before or 2 or $5 \mathrm{hr}$ after AMPA injection resulted in no significant protection against decreases in ChAT and GAD activities.

The effect of delayed MK-801 administration was also tested against kainate-induced neuronal degeneration in the rat hippocampus. Injection of $1 \mathrm{nmol}$ kainate into the dorsal hippocampus in 5 animals resulted in destruction of CA3 and CA4 pyramidal neurons in all animals (Fig. $2 E$ ) and additional involvement of CA1 neurons in 3 animals. In another group of 5 animals, administration of MK-801 (10 mg/kg, i.p.) $1 \mathrm{hr}$ after kainate injection failed to prevent the loss of CA3 and CA4 pyramidal neurons (Fig. $2 F$ ). 

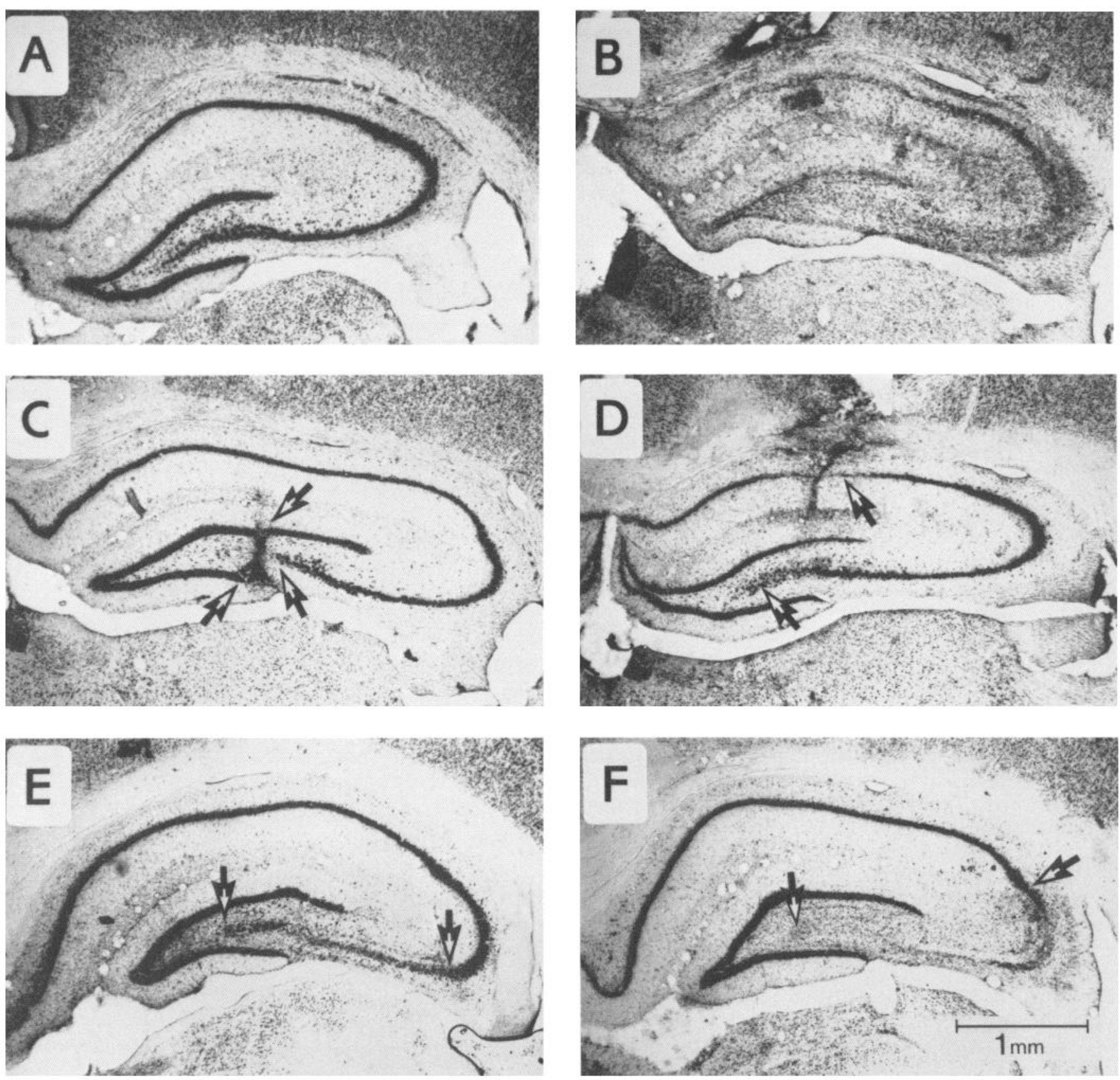

Figure 2. Protection by MK-801 of quinolinate-induced neurotoxicity in the rat hippocampus and lack of effect upon kainate-induced neurotoxicity. Light micrographs of $40 \mu \mathrm{m}$ cresyl violet-stained coronal sections of rat brain $7 \mathrm{~d}$ following intrahippocampal injection. $A$, Saline injection. $B$, Injection of $60 \mathrm{nmol}$ quinolinate. Note complete loss of hippocampal pyramidal and granule cells and marked gliosis. $C$, Treatment with $10 \mathrm{mg} /$ $\mathrm{kg} \mathrm{MK}-8011 \mathrm{hr}$ prior to injection of $60 \mathrm{nmol}$ quinolinate. Protection of hippocampal neurons is essentially complete, even at the site of injection (arrows). D, Treatment with $10 \mathrm{mg} / \mathrm{kg} \mathrm{MK}-8011 \mathrm{hr}$ after injection of $60 \mathrm{nmol}$ quinolinate. All hippocampal neurons are protected with the exception of an area of CA1 and CA4 pyramidal cells at the immediate site of injection (arrows). E. Injection of 1 nmol kainate. Note loss of CA3 and CA4 pyramidal cells (between arrows). F, Treatment with $10 \mathrm{mg} / \mathrm{kg}$ MK-801 (i.p.) $1 \mathrm{hr}$ after injection of $1 \mathrm{nmol}$ kainate. MK-801 failed to prevent the kainate-induced loss of CA3 and CA4 pyramidal neurons (between arrows).

\section{Effect of CPP on striatal neurodegeneration caused by quinolinate}

To determine if delayed administration of another selective NMDA receptor antagonist could prevent striatal neurodegeneration caused by quinolinate, the competitive antagonist CPP (Harris, et al., 1986; Lehmann et al., 1987) was injected i.p. 1 $\mathrm{hr}$ after intrastriatal injection of $200 \mathrm{nmol}$ quinolinate. As shown in Table 3, administration of $100 \mathrm{mg} / \mathrm{kg}$ CPP resulted in significant, but incomplete, protection against the reductions of ChAT and GAD activities caused by quinolinate.

\section{Effect of isoflurane anesthesia}

An experiment was designed to evaluate the possibility that the ability of delayed administration of MK-801 to protect against quinolinate-induced striatal neurodegeneration was due to an 
Table 2. Effect of MK-801 (10 mg/kg, i.p.) on reductions of rat striatal ChAT and GAD activities caused by kainate and AMPA

\begin{tabular}{|c|c|c|c|c|}
\hline \multirow[b]{2}{*}{ Excitotoxin } & \multirow[b]{2}{*}{ Control } & \multicolumn{3}{|c|}{$\%$ Decrease of enzyme activity } \\
\hline & & $\begin{array}{l}\text { MK- } 801 \\
1 \mathrm{hr} \text { before }\end{array}$ & $\begin{array}{l}\text { MK-801 } \\
2 \mathrm{hr} \text { after }\end{array}$ & $\begin{array}{l}\text { MK-801 } \\
5 \mathrm{hr} \text { after }\end{array}$ \\
\hline \multicolumn{5}{|c|}{ Kainate (5 nmol) } \\
\hline ChAT & $62.0 \pm 5.8(5)$ & $63.6 \pm 5.5(5)$ & $61.4 \pm 5.7(5)$ & $46.5 \pm 8.5$ \\
\hline GAD & $63.1 \pm 5.5(5)$ & $63.9 \pm 4.0(5)$ & $62.8 \pm 3.0(5)$ & $52.1 \pm 14.8(4)$ \\
\hline \multicolumn{5}{|c|}{ AMPA (50 nmol) } \\
\hline ChAT & $40.5 \pm 7.4(5)$ & $59.4 \pm 9.4(5)$ & $62.2 \pm 4.9(5)$ & $57.5 \pm 10.8(5)$ \\
\hline GAD & $74.9 \pm 4.9(5)$ & $85.1 \pm 3.3(5)$ & $84.8 \pm 3.1(5)$ & $83.8 \pm 6.2$ \\
\hline
\end{tabular}

Enzyme measurements were made in homogenates of striatum from rats killed $7 \mathrm{~d}$ after intrastriatal kainate or AMPA injection. Values are the percentage decrease of enzyme activity in the injected versus contralateral striatum and are the means \pm SEM of the number of animals given in parentheses. MK-801-treated groups were not significantly different from controls (Dunnett's test).

interaction with the surgical anesthetic used. In all of the experiments described so far, excitotoxin injections were made under Equithesin anesthesia, from which rats regain the righting reflex approximately $2 \mathrm{hr}$ after excitotoxin injection. A group of 10 rats was injected with $200 \mathrm{nmol}$ quinolinate into the striatum under $2 \%$ isoflurane, $70 \% \mathrm{~N}_{2} \mathrm{O}, 30 \% \mathrm{O}_{2}$ anesthesia. Animals recovered the righting reflex within $30 \mathrm{~min}$ and developed behaviors typically observed following unilateral striatal injections of quinolinate (clonic-tonic movements of contralateral forepaws, barrel rotation, etc. - see Foster et al., 1983). At $2 \mathrm{hr}$ after quinolinate injection, 5 animals were injected i.p. with $10 \mathrm{mg} / \mathrm{kg} \mathrm{MK}-801$ and the remaining 5 animals remained untreated as controls. As shown in Table 3, measurement of striatal ChAT and GAD activities in these animals $7 \mathbf{d}$ later indicated a protective effect of MK-801 that, although less pronounced, was comparable with that observed when Equithcsin was used as an anesthetic (cf. Fig. 3).

\section{Discussion}

\section{Specificity of $M K-801$ for NMDA receptor-mediated} neurodegeneration

Electrophysiological experiments in vitro (Kemp et al., 1986; Wong et al., 1986) and in vivo (Davies et al., 1988) indicate that MK-801 is a selective antagonist of NMDA receptor-mediated neuronal depolarization. The present results and those of our previous study (Foster et al., 1987a) demonstrate that MK-801 is also a selective antagonist of NMDA receptor-mediated neuronal degeneration in the rat brain. Thus, in the rat striatum MK-801 dose-dependently protected against the loss of intrinsic neurons caused by local injection of NMDA (Foster et al., 1987a) and the endogenous NMDA receptor agonist quinolinate (present study). However, striatal neurodegeneration caused by intrastriatal injection of kainate or AMPA could not be prevented by MK-801 at doses and times of administration that were protective with respect to NMDA and quinolinate (Foster et al., $1987 \mathrm{a}$, and present study). In the rat hippocampus, a $10 \mathrm{mg} / \mathrm{kg}$ dose of MK-801 almost completely prevented the loss of neurons caused by local injection of NMDA (Foster et al., 1987a) and quinolinate but not that caused by kainate. Thus, when administered systemically in vivo MK-801 prevents neuronal degeneration caused by NMDA receptor agonists (NMDA and quinolinate) but not that induced by agonists selective for the quisqualate and kainate subtypes of excitatory amino acid receptors.

A dose of $10 \mathrm{mg} / \mathrm{kg} \mathrm{MK}-801$ caused virtually complete protection against all doses of quinolinate injected into the striatum. Even at the highest dose of quinolinate $(600 \mathrm{nmol})$, which, in untreated rats, resulted in degeneration of the entire striatum and reduction of ChAT and GAD values to $<4 \%$ of control values, pretreatment with $10 \mathrm{mg} / \mathrm{kg} \mathrm{MK}-801$ maintained ChAT and GAD activities at 91 and $82 \%$ of control, respectively (see Table 1). The blockade of NMDA depolarizations by MK-801

Table 3. Prevention of quinolinate-induced reductions of rat striatal ChAT and GAD activities by CPP and by MK-801 following isoflurane anesthesia

\begin{tabular}{lllll} 
& \multicolumn{4}{l}{ \% Decrease of striatal enzyme activity } \\
\cline { 2 - 4 } Experiments & \multicolumn{3}{l}{ ChAT } & GAD \\
\hline $\begin{array}{l}\text { Experiment 1 } \\
\quad \text { Control }\end{array}$ & $65.1 \pm 7.5$ & $(5)$ & $77.2 \pm 3.7 \quad(5)$ \\
$\quad$ CPP 1 hr after quinolinate & $32.4 \pm 16.4^{a}(5)$ & $41.0 \pm 12.5^{a}(5)$ \\
Experiment 2 & & & & \\
$\quad$ Control & $85.1 \pm 4.2$ & $(5)$ & $87.7 \pm 2.5$ & $(5)$ \\
MK-801 2 hr after quinolinate & $17.0 \pm 8.6^{b}$ & $(5)$ & $61.6 \pm 2.4^{b}$ & $(5)$
\end{tabular}

Enzyme measurements were made in homogenates of striatum from rats killed $7 \mathrm{~d}$ after intrastriatal quinolinate injection. Values are the percentage decrease of enzyme activity in the injected versus contralateral striatum and are the means \pm SEM of the number of animals given in parentheses. In Experiment 1, 200 nmol quinolinate was injected under Equithesin anesthesia, and CPP, $100 \mathrm{mg} / \mathrm{kg}$, was injected i.p. $1 \mathrm{hr}$ later. In Experiment 2, 200 nmol quinolinate was injected under $2 \%$ isoflurane $/ 70 \% \mathrm{~N}_{2} \mathrm{O} / 30 \% \mathrm{O}_{2}$ ancsthcsia, and $\mathrm{MK}-801,10 \mathrm{mg} / \mathrm{kg}$, was injected i.p. $2 \mathrm{hr}$ later.

${ }^{a} p<0.05,{ }^{b} p<0.01$ (significantly different from controls by Dunnett's test). 

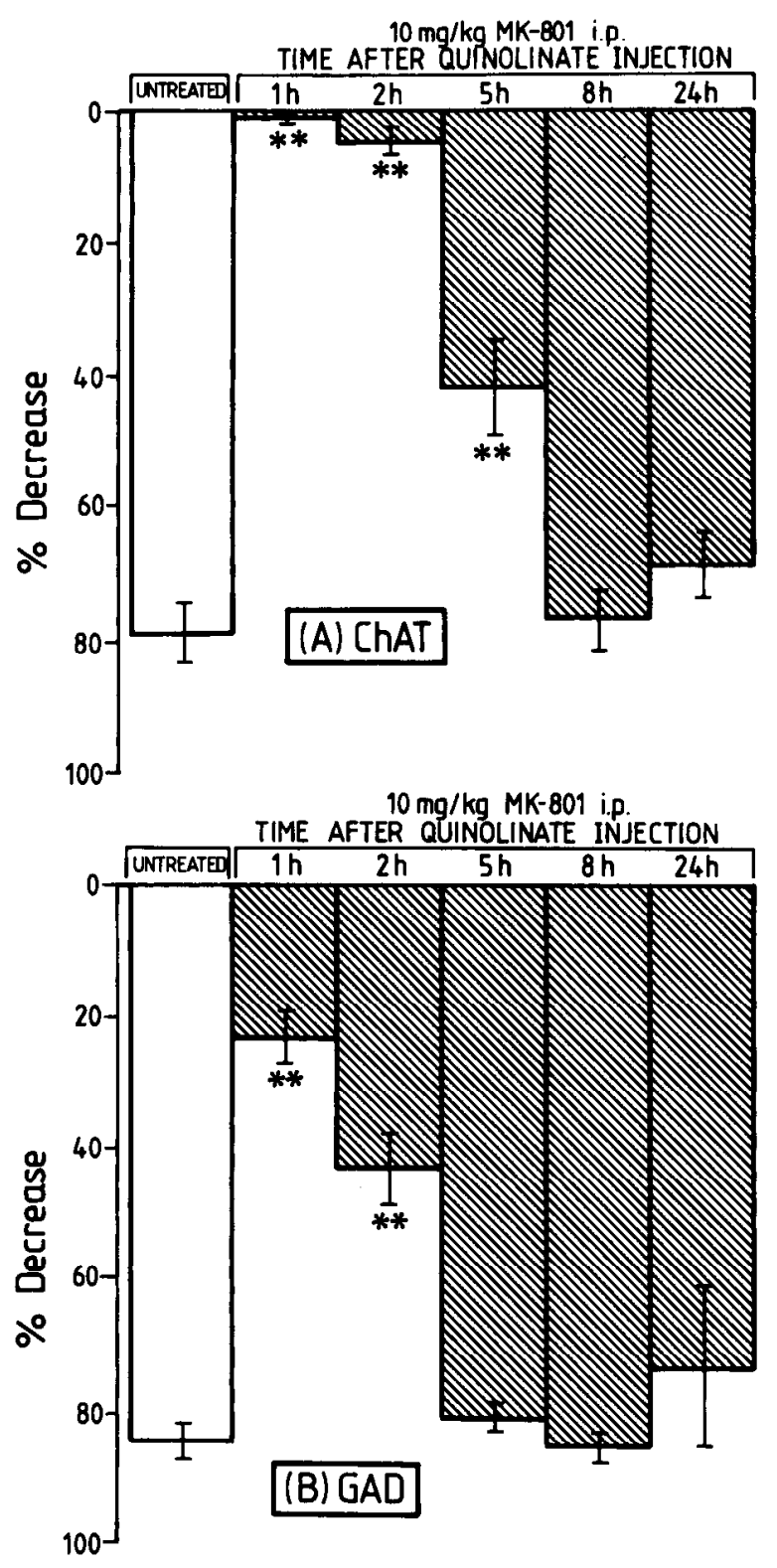

Figure 3. Protection of quinolinate-induced reductions in striatal ChAT $(A)$ and GAD $(B)$ activities by MK-801 administered after quinolinate injection. Animals received an intrastriatal injection of $200 \mathrm{nmol}$ quinolinate and were then treated with a single dose of MK-801 $(10 \mathrm{mg} / \mathrm{kg}$, i.p.) at the indicated times. Enzyme measurements were made $7 \mathrm{~d}$ later. Values are the percentage decrease of enzyme activity in the injected versus the contralateral striatum and are the means \pm SEM of 5-15 animals per group. ${ }^{* *} p<0.01$ compared with controls (Dunnett's test).

in vitro is noncompetitive and insurmountable by further addition of agonist (Kemp et al., 1986; Wong et al., 1986). MK801 is proposed to act by blocking the open state of the NMDA receptor associated ion channel (Kemp et al., 1987); therefore, it does not compete directly with agonists for the receptor. The characteristics of the protection by MK-801 of quinolinate-induced neurotoxicity in vivo are consistent with this mechanism of antagonism.

\section{Protection of neurons by delayed administration of $M K-801$}

A most surprising finding was that the degeneration of neurons caused by intracerebral injection of NMDA or quinolinate was

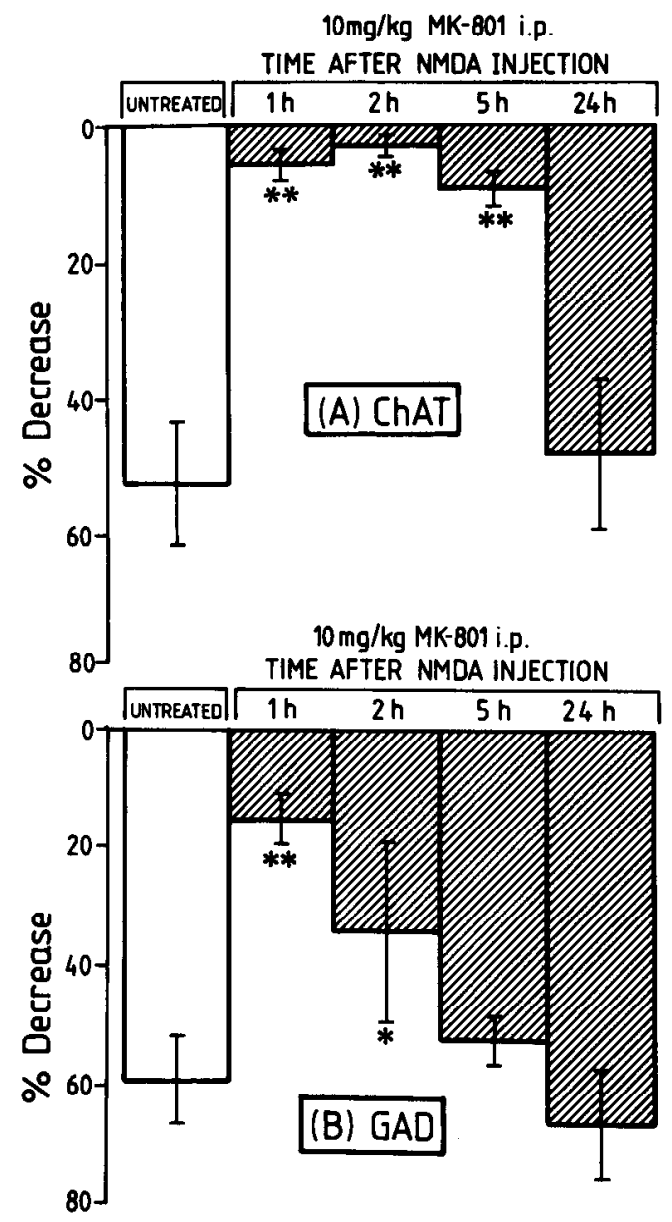

Figure 4. Protection of NMDA-induced reductions in striatal ChAT $(A)$ and $\operatorname{GAD}(B)$ activities by MK- 801 administered after NMDA injection. Animals received an intrastriatal injection of $200 \mathrm{nmol} \mathrm{NMDA}$ and were then treated with a single dosc of MK-801 $(10 \mathrm{mg} / \mathrm{kg}$, i.p.) at the indicated times. Enzyme measurements were made $7 \mathrm{~d}$ later. Values are the percentage decrease of enzyme activity in the injected versus the contralateral striatum and are the means \pm SEM of 3-10 animals per group. ${ }^{*} p<0.05 ;{ }^{* *} p<0.01$ compared with controls (Dunnett's test).

prevented when a single dose of MK-801 was administered up to $5 \mathrm{hr}$ following excitotoxin injection. The features of this protection of neurons by delayed administration of MK-801 are as follows: (1) only neurodegeneration caused by NMDA receptor agonists (NMDA and quinolinate) was prevented and kainateand AMPA-induced neuronal loss was unaffected by MK-801 administered up to $5 \mathrm{hr}$ after excitotoxin injection; (2) protection of neurons occurred in both striatum and hippocampus (the only brain regions studied); (3) the protection was not equal for all neurons since in the striatum administration of MK-801 5 $\mathrm{hr}$ after excitotoxin injection partially protected cholinergic neurons but could not prevent degeneration of GABAergic neurons; (4) the apparent potency of MK-801 as an antagonist of neurodegeneration was greater when it was administered after quinolinate injection than before, suggesting that the critical period for protection occurs following quinolinate injection; and (5) protection of neurons by delayed MK- 801 administration was not due to a specific interaction with the surgical anesthetic used or the length of time animals spent in anesthesia since equivalent results were obtained using Equithesin or isoflurane $/ \mathrm{N}_{2} \mathrm{O} / \mathrm{O}_{2}$.

Therefore, following intracerebral injection of an NMDA re- 

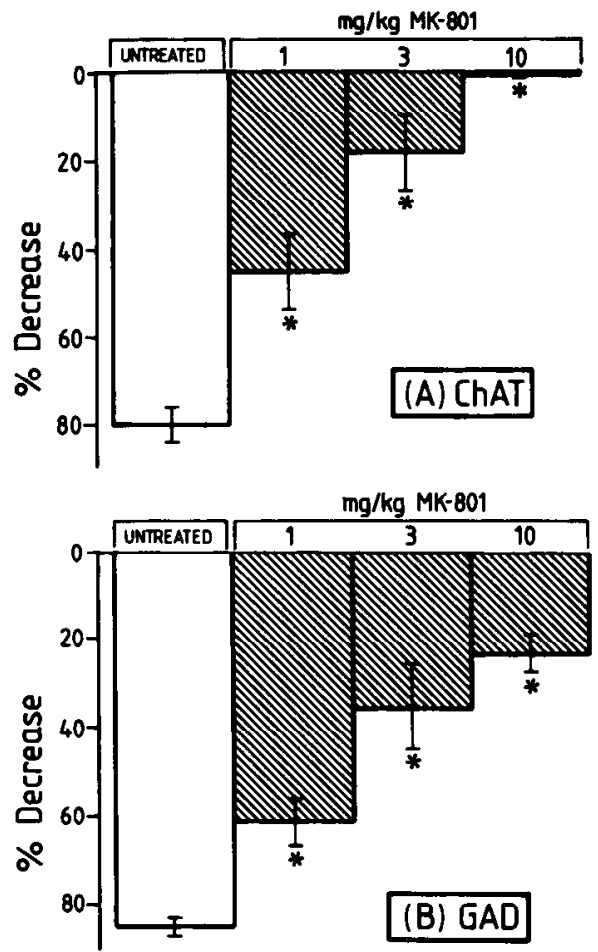

Figure 5. Dose-dependent protection of quinolinate-induced reductions in striatal ChAT $(A)$ and GAD $(B)$ activities by MK-801 administered $1 \mathrm{hr}$ after quinolinate. Animals received an intrastriatal injection of $200 \mathrm{nmol}$ quinolinate and were treated $1 \mathrm{hr}$ later with MK-801 (i.p.) at a dose of 1,3 , or $10 \mathrm{mg} / \mathrm{kg}$. Enzyme measurements were made $7 \mathrm{~d}$ later. Values are the percentage decrease of enzyme activity in the injected versus the contralateral striatum and are the means \pm SEM of $5-15$ animals in each group. ${ }^{*} p<0.01$ compared with control (Dunnett's test).

ceptor agonist, neurons in the striatum or hippocampus do not die as an immediate consequence of NMDA receptor activation, but undergo a delayed form of degeneration that can be prevented by MK-801 administered $1-5 \mathrm{hr}$ after excitotoxin injection.

\section{Mechanism of delayed neuronal degeneration}

What is the mechanism by which NMDA receptor agonists cause delayed degeneration? First, it seems improbable that the delayed degenerative events are due to injected quinolinate or NMDA remaining in the vicinity of the vulnerable neurons over a period of several hours. Following injection of ${ }^{3} \mathrm{H}$-quinolinate into the striatum, levels of striatal radioactivity decline with a half-life of $22 \mathrm{~min}$ (Foster et al., 1984), and after injection into the hippocampus, only $3 \%$ of ${ }^{3} \mathrm{H}$-quinolinate remains in hippocampal tissue 25 min later (Schwarcz et al., 1984). Thus, it seems unlikely that such low levels of residual quinolinate (or NMDA) could mediate degenerative events that occur as long as $5 \mathrm{hr}$ after injection. Second, quinolinate is not metabolized following intrastriatal or hippocampal injection (Foster et al., 1984; Schwarcz et al., 1984), ruling out the possibility that an excitotoxic metabolite slowly accumulates. Therefore, one plausible mechanism for these effects is that local injection of an NMDA agonist sets in motion a process that continues over several hours and leads to neuronal death and that this delayed process involves intrinsic neuronal mechanisms, not the exogenous NMDA agonist itself. This idea is supported by experi- ments in tissuc culture which indicate that the continual presence of an excitatory amino acid is not required to produce neuronal degeneration and that pharmacological intervention in the period following a brief exposure to glutamate can prevent neuronal loss (Rothman et al., 1987).

The fact that neuronal degeneration is prevented by delayed administration of MK-801 (whose selectivity for NMDA receptors is discussed above) indicates that NMDA receptor activation participates in the delayed degenerative process. Furthermore, delayed administration of the selective and competitive NMDA receptor antagonist CPP (Harris et al., 1986; Lehmann et al., 1987), which bears no structural similarity to MK-801, also partially prevented quinolinate-induced neurotoxicity (Table 3), further strengthening the argument that the delayed degenerative process requires activation of NMDA receptors and that the neuroprotective effects of MK-801 are not due to some unsuspected pharmacological action of this compound. Again, tissue culture experiments support an NMDA receptor involvement since the selective, competitive NMDA antagonist D-2amino-5-phosphonovalerate (D-AP5) prevents neurodegeneration when applied to cultured neurons in the period following exposure to glutamate (Rothman et al., 1987). Our results indicate that the initiation of the delayed degenerative process that is blocked by MK-801 specifically requires NMDA receptor activation. Thus, delayed administration of MK-801 did not prevent the degeneration of neurons caused by kainate and AMPA. This suggests that the delayed degenerative process does not result from excessive depolarization of neurons per se (see also Rothman et al., 1987) since the vulnerable neurons in the striatum and hippocampus can be depolarized by activation of quisqualate and kainate receptors (Collingridge et al., 1983; Herrling et al., 1983).

At face value, the present results are at variance with the original concepts of the "excitotoxic hypothesis" (Olney, 1974). When neurons in vitro are chronically exposed to high concentrations of excitatory amino acids, they degenerate rapidly by a process involving entry of $\mathrm{Na}^{+}, \mathrm{Cl}^{-}$, and water, resulting in osmotic lysis (Rothman and Olney, 1987). However, brief exposure of neurons to glutamate or NMDA in vitro results in a $\mathrm{Ca}^{2+}$-dependent form of neurodegeneration (Choi, 1985, 1987; Garthwaite and Garthwaite, 1986), which is of a delayed type (Choi, 1985, 1987) and can be blocked by addition of competitive NMDA antagonists in the period following agonist exposure (Rothman et al., 1987). Therefore, our results in vivo agree with these in vitro studies, and it may be that the degeneration of neurons caused by direct excitotoxin injection in vivo is of the delayed $\mathrm{Ca}^{2+}$-dependent type, rather than the rapid $\mathrm{Cl}^{-}$dependent type.

Our results with selective NMDA agonists and MK-801 indicate that NMDA receptor activation both initiates the delayed process leading ultimately to neuronal death and is essential for its expression. It is possible that the mechanisms underlying these events are the same as those occurring during long-term potentiation or kindling (Goddard et al., 1969; Bliss and Lomo, 1973). In both cases, evidence indicates that NMDA receptor activation establishes a permanent change in activity at cxcitatory amino acid-using synapses (Collingridge et al., 1983; Mody and Heinemann, 1987; Stelzer et al., 1987). A further possibility is that delayed degeneration is a consequence of the preceding loss of inhibitory influences. An early failure of inhibition has been observed in a model of experimental epilepsy where subsequent degeneration of hippocampal neurons occurs (Sloviter, 
1987), and a lack of GABAergic tone has been proposed as the cause of experimentally induced delayed degeneration of neurons in the substantia nigra (Saji and Reis, 1987). It is therefore interesting to note that in the present studies GABAergic neurons appeared to degenerate earlier than cholinergic neurons in the striatum following quinolinate or NMDA injection. Thus, it is possible that degeneration of cholinergic neurons is secondary to the loss of GABAergic neurons, which usually exert an inhibitory influence upon them.

Delayed degeneration of neurons is a phenomenon observed in animal models of cerebral ischemia (Kirino, 1982; Pulsinelli et al., 1982; Gill et al., 1987a), and recent evidence suggests that delayed degeneration occurs in the hippocampus of humans following cardiorespiratory arrest (Petito et al., 1987). The delayed death of neurons that occurs in gerbils subjected to a brief period of cerebral ischemia can be prevented by MK- 801 administered as a single dose during or up to $24 \mathrm{hr}$ after the initial insult (Gill et al., 1988). Therefore, the delayed neuronal loss described here in response to intracerebral injection of NMDA agonists may occur by similar mechanisms to those which cause neurodegeneration in cerebral ischemia. It is hoped that further investigation of this delayed degenerative process will shed light on the mechanisms underlying neurodegenerative phenomena in pathological situations and may provide further clues for therapeutic strategies to alleviate them.

\section{References}

Benveniste, H., J. Drejer, A. Schousboe, and N. H. Diemer (1984) Elevation of extracellular concentrations of glutamate and aspartate in rat hippocampus during transient cerebral ischaemia monitored by intracerebral microdialysis. J. Neurochem. 43: 1369-1374.

Bliss, T. V. P., and T. Lomo (1973) Long-lasting potentiation of synaptic transmission in the dentate area of the anaesthetised rabbit following stimulation of the perforant path. J. Physiol. (Lond.) 232: 331-356.

Bull, G., and B. Oderfeld-Novak (1971) Standardisation of a radiochemical assay of cholineacetyltransferase and a study of the activation of the enzyme in rabbit brain. J. Neurochem. 18: 935-941.

Choi, D. W. (1985) Glutamate neurotoxicity in cortical cell culture is calcium dependent. Neurosci. Lett. 58: 293-297.

Choi, D. W. (1987) Ionic dependence of glutamate neurotoxicity. J. Neurosci. 7: 369-379.

Collingridge, G. L., S. J. Kehl, and H. McLennan (1983) Excitatory amino acids in synaptic transmission in the Schaffer collateral-commissural pathway of the rat hippocampus. J. Physiol. (Lond.) 334: $33-46$.

Coyle, J. T., and R. Schwarcz (1976) Lesion of striatal neurones with kainic acid provides a model for Huntington's chorca. Nature 262: 244-246.

Davies, S. N., D. Martin, J. D. Millar, J. A. Aram, J. Church, and D. Lodge (1988) Differences in results from in vivo and in vitro studies on the use-dependency of $\mathrm{N}$-methylaspartate antagonism by MK-801 and other phencyclidine receptor ligands. Eur. J. Pharmacol. 145: 141-151.

Foster, A. C., and G. E. Fagg (1984) Acidic amino acid binding sites in mammalian neuronal membranes: Their characteristics and relationship to synaptic receptors. Brain Res. Rev. 7: 103-164.

Foster, A. C., J. F. Collins, and R. Schwarcz (1983) On the excitatory properties of quinolinic acid, 2,3-piperidine dicarboxylic acids and structurally related compounds. Neuropharmacology 22: 1331-1342.

Foster, A. C., L. P. Miller, W. H. Oldendorf, and R. Schwarcz (1984) Studies on the disposition of quinolinic acid after intracerebral or systemic administration in the rat. Exp. Neurol. 84: 428-440.

Foster, A. C., R. Gill, J. A. Kemp, and G. N. Woodruff (1987a) Systemic administration of MK-801 prevents N-methyl-D-aspartate-induced neuronal degeneration in rat brain. Neurosci. Lett. 76: 307311.

Foster, A. C., R. Gill, and G. N. Woodruff (1987b) MK-801 prevents degeneration of striatal neurones caused by intrastriatal injection of quinolinic acid. Br. J. Pharmacol. Proc. (Suppl.) 90: 7P.

Foster, A. C., R. Gill, and G. N. Woodruff $(1987 \mathrm{c})$ A delayed excitotoxic mechanism mediates the degeneration of rat striatal neurones caused by N-methyl-D-aspartate and quinolinate. Soc. Neurosci. Abstr. 13: 287.6 .

Fuxe, K., P. J. Roberts, and R. Schwarcz (1983) Excitotoxins, Macmillan, London.

Garthwaite, G., and J. Garthwaite (1986) Neurotoxicity of excitatory amino acid receptor agonists in rat cerebellar slices: Dependence on calcium concentration. Neurosci. Lett. 66: 193-198.

Gill, R., A. C. Foster, and G. N. Woodruff (1987a) Systemic administration of MK-801 protects against ischaemia-induced hippocampal neurodegeneration in the gerbil. J. Neurosci. 7: 3343-3349.

Gill, R., A. C. Foster, and G. N. Woodruff (1987b) Systemic administration of MK-801 protects against ischaemic neuropathology in rats. Br. J. Pharmacol. Proc. (Suppl.) 91: 311P.

Gill, R., A. C. Foster, and G. N. Woodruff (1988) MK-801 is neuroprotective in gerbils when administered during the post-ischaemic period. Neuroscience 25: 847-855.

Goddard, G. V., D. C. McIntyre, and C. K. Leech (1969) A permanent change in brain function resulting from daily clectrical stimulation. Exp. Neurol. 25: 295-330.

Hagberg, H., A. Lehmann, M. Sandberg, B. Nystrom, I. Jacobson, and A. Hamberger (1985) Ischaemia-induced shift of inhibitory and excitatory amino acids from intra- to extracellular compartments. $J$. Cereb. Blood Flow Metab. 5: 413-419.

Harris, E. W., A. H. Ganong, D. T. Monoghan, J. C. Watkins, and C. W. Cotman (1986) Action of 3-((+)-2-carboxypiperazin-4-yl)-propyl-1-phosphonic acid (CPP): A new and highly potent antagonist of $\mathrm{N}$-methyl-D-aspartate receptors in the hippocampus. Brain Res. 382: 174-177.

Herrling, P. L., R. Morris, and T. E. Salt (1983) Effects of excitatory amino acids and their antagonists on membrane and action potentials of cat caudate neurones. J. Physiol. (Lond.) 339: 207-222.

Kemp, J. A., T. Priestley, and G. N. Woodruff (1986) MK-801, a novel, orally active anticonvulsant is a potent, non-competitive $\mathrm{N}$-methyl-D-aspartate receptor antagonist. Br. J. Pharmacol. Proc. (Suppl.) 89: 535P.

Kemp, J. A., A. C. Foster, and E. H. F. Wong (1987) Non-competitive antagonists of excitatory amino acid receptors. Trends Neurosci. 10 : 294-298.

Kirino, T. (1982) Delayed neuronal death in the gerbil hippocampus following ischaemia. Brain Res. 239: 57-69.

Krogsgaard-Larsen, P., T. Honore, J. J. Hansen, D. R. Curtis, and D. Lodge (1980) New class of glutamate agonists structurally related to ibotenic acid. Nature 284: 64-66.

Lehmann, J., J. Schneider, S. McPherson, D. E. Murphy, P. Bernard, C. Tsai, D.A. Bennett, G. Pastor, D. J. Steel, C. Boehm, D. L. Cheney, J. M. Liebman, M. Williams, and P L. Wood (1987) CCP, a selective $\mathrm{N}$-methyl-D-aspartate (NMDA)-type receptor antagonist: Characterisation in vitro and in vivo. J. Pharmacol. Exp. Ther. 240:737-746.

Lucas, D. R., and J. P. Newhouse (1957) The toxic effect of sodium L-glutamate on the inner layers of the retina. Arch. Opthalmol. 58 . 193-210.

McGeer, E. G., and P. L. McGeer (1976) Duplication of biochemical changes of Huntington's chorea by intrastriatal injections of glutamic and kainic acids. Nature 263: 517-519.

Mody, I., and U. Heinemann (1987) NMDA receptors of dentate gyrus granule cells participate in synaptic transmission following kindling. Nature 326: 701-704.

Morgan, I. G. (1987) AMPA is a powerful neurotoxin in the chicken retina. Neurosci. Lett. 79: 267-271.

Olney, J. W. (1974) Toxic effects of glutamate and related amino acids on the developing central nervous system. In Heritable Disorders of Amino Acid Metabolism, W. L. Nyhan, ed., pp. 501-512, Macmillan, New York.

Olney, J. W., O. L. Ho, and V. Rhee (1971) Cytotoxic effects of acidic and sulphur containing amino acids on the infant mouse central nervous system. Exp. Brain Res. 14: 61-76.

Petito, C. K., E. Feldmann, W. A. Pulsinelli, and F. Plum (1987) Delayed hippocampal damage in humans following cardiorespiratory arrest. Neurology 37: 1281-1286.

Pulsinelli, W. A., J. B. Brierley, and F. Plum (1982) Temporal profile of neuronal damage in a model of transient ischaemia. Ann. Neurol. 11: $491-499$. 
Rothman, S. (1984) Synaptic release of excitatory amino acid neurotransmitter mediates anoxic neuronal death. J. Neurosci. 4: 1884 1891.

Rothman, S. M., and J. W. Olney (1987) Excitotoxicity and the NMDA receptor. Trends Neurosci. 10: 299-302.

Rothman, S. M., J. H. Thurston, and R. E. Hanhart (1987) Delayed neurotoxicity of excitatory amino acids in vitro. Neuroscience 22 . $471-480$.

Saji, M., and D. J. Reis (1987) Delayed transneuronal death of substantia nigra neurons prevented by $\gamma$-aminobutyric acid agonist. Science 235: 66-69.

Schwarcz, R., D. Sholtz, and J. T. Coyle (1978) Structure-activity relations for the neurotoxicity of kainic acid derivatives and glutamate analogues. Neuropharmacology 17: 145-151.

Schwarcz, R., W. O. Whetsell, Jr., and R. M. Mangano (1983) Quinolinic acid: An endogenous metabolite that produces axon-sparing lesions in rat brain. Science 219:316-318.

Schwarcz, R., G. S. Brush, A. C. Foster, and E. D. French (1984) Seizure activity and lesions after hippocampal quinolinic acid injection. Exp. Neurol. 84: 1-17.

Simon, R. P., J. H. Swan, T. Griffiths, and B. S. Meldrum (1984) Blockade of $\mathrm{N}$-methyl-D-aspartate receptors may protect against ischemic damage in the brain. Science 226: 850-852.
Sloviter, R. S. (1987) Decreased hippocampal inhibition and a selective loss of interneurons in experimental epilepsy. Science $235: 73$ 76.

Stelzer, A., N. T. Slater, and G. ten Bruggencate (1987) Activation of NMDA receptors blocks GABAergic inhibition in an in vitro model of epilepsy. Nature 326: 698-701.

Stone, T. W., and M. N. Perkins (1981) Quinolinic acid: A potent endogenous excitant at amino acid receptors in CNS Eur. J. Pharmacol. 72: 411-412.

Watkins, J. C., and R. H. Evans (1981) Excitatory amino acid transmittcrs. Annu. Rev. Pharmacol. Toxicol. 21: 165-204.

Wieloch, T. (1985) Neurochemical correlates to selective neuronal vulnerability. Prog. Brain Res. 63: 69-85.

Wilson, S. H., B. K. Schrier, J. L. Farber, E. J. Thompson, R. N. Rosenberg, A. J. Blume, and M. W. Nirenberg (1972) Markers for gene expression in cultured cells from the nervous system. J. Biol. Chem. 247: 3159-3169.

Wong, E. H. F., J. A. Kemp, T. Priestley, A. R. Knight, G. N. Woodruff, and L. L. Iversen (1986) The anticonvulsant MK-801 is a potent N-methyl-D-aspartate antagonist. Proc. Natl. Acad. Sci. USA 83: 7104-7108. 